\title{
QUALITATIVE EXPLORATION OF SOCIAL FACTORS THAT UNDERLY MOTIVATIONS OF MEDICAL STUDENTS TO ASPIRE TO THE PROFESSION
}

\author{
González-Amarante MP* and Olivares-Olivares SL
}

Tecnologico de Monterrey, Escuela de Medicina y Ciencias de la Salud, Mexico

\begin{abstract}
Aspiring physicians' motivational discourses have mostly delineated intrinsic versus extrinsic factors in the literature, lacking further comprehension of factors underpinning such decision. The purpose of this qualitative study is to deepen the understanding of factors and motivations that lead students to aspire to the medical profession.

Semi-structured interviews were applied to 55 medical students from 3 Universities in Mexico, transcriptions were submitted to iterative rounds of coding for analysis using grounded theory. Predominant reasons to enter the profession were: I) Interest in the medical science, II) Aspiring to honorability and status, III) Having a physician family member, IV) Personal experience with illness and V) Desire to help (altruism). Beyond discourse, one striking finding was that most chose their career lacking conscious reasoning and autonomy either because a)ideation/decision was conceived during childhood, b) lacked clear motivation arguments and c)had significant external influence (particularly from parents) on their choice. Such findings helped develop a model that recognizes factors that underly the conscious motivations that students exhibit including: 1) Parental desire/pressure. 2) Proximity of family medical models and lack of exposure to other disciplines. 3) Idealization of the doctor figure during childhood. 4) Influence of television programs. 5) The notion that the career ensures future economic stability/prosperity. 6) Desire of social mobility. The prior socialization of students conditions an aspiration based on a perception of heightened professional status of the medical profession that may differ from the current context. The motivations have an extrinsic preponderance and do not reflect autonomy and adequate understanding of the implications of studying medicine and the future practice of the profession. This can generate problems about their own satisfaction and identity and with respect to the social impact in the exercise of their future role.
\end{abstract}

Keywords: motivations, medical students, medical profession, medical education, socialization

\section{Introduction}

The issue of the motivations for aspiring medical professionals is one of wide interest in the literature. It is particularly significant for medical educators and for agents on the political scale concerned with the attraction and management of human resources for health, in the understanding that it is transcendental to society. 
Regarding educational interests, empirical studies that address the motivation of applicants to the medical profession usually yield information to determine the requirements and selection variables for entering the program, with the understanding that they constitute predictors of learning and academic performance (Yousefy et al. 2012, Torres-Acosta et al. 2013, Vives-Varela et al. 2014, Wouters et al. 2016,Torres- Román et al. 2018) and for the design of training strategies to nurture and increase motivation through the continuum of the career. Some medical schools consider this aspect in interviews or application letters as one of the requirements to account for admission.

Recently, particular interest in this topic has been evidenced across several countries, reflected in empirical studies of quantitative and qualitative nature. It is clear that there is relative variability in their results. Most of the studies are on newly ascribed medical students and seek to categorize the motivations for their career choice by distinguishing those of intrinsic versus extrinsic nature. Intrinsic motivation is defined as the involvement on an activity for inherent satisfactions and not for consequences that are separable; On the other hand, extrinsic motivation corresponds to a construct that implies that an activity is carried out to achieve a result, meaning that it has an instrumental value (Ryan and Deci, 2000).

Some studies have reported a majority of students motivated by intrinsic reasons such as helping others or the feeling of self-fulfillment (McHugh et al. 2011, Lermanda and Meyer, 2014, PhinderPuente et al. 2014, Wasityastuti et al. 2018, Flores et al. 2019) Other studies have shown a prevalence of external motivations that include expectations of economic income and social prestige (Perales $e t$ al. 2014, Fernandini, 2018) Some authors have challenged the dichotomy to include a category of amotivational postures to represent students who do not present classifiable motivations under either of the two connotations (Wasityastuti et al. 2018, Foong et al. 2018).

Regarding other relevant factors that have been explored, the difference in the motivations of students according to gender stands out, for which a greater interest in social prestige and economic income has been consistently found for males than their counterpart (Wierenga et al. 2003, Millán et al. 2005, McHugh et al. 2011) Other more in-depth studies have highlighted the importance of social class as a conditioning factor (Cardozo, 2009, Fernandini, 2018).

A recent systematic review of the literature that included 24 articles correlated the results of empirical studies according to the income level of the countries. It is worth mentioning that there was no study that represented Mexico in this review. They argue that motivations correlate with Maslow's hierarchy of needs according to the income level of the country. The problem that these authors admit is that there are no studies of low-income countries, and with respect to those of the lower middle class, the results are variable. Upper-middle-income countries, which would correspond to Mexico's classification according to the World Bank, correlate to the middle zone of Maslow's hierarchy; the main motivators for this stratum are usually job security, social status, and parental desire (Goel et al. 2018). This differs from the studies that have declared altruistic motivations to be predominant in career choice.

In Mexico, two quantitative studies that used a survey as the data collection method rendered contrasting results. One study that applied a 12 item questionnaire to highschool students aspiring to the medical career concluded that intrinsic motivations were consistently higher than extrinsic ones (Flores et al. 2019). The second study was applied to medical students in a public university, the two 
most chosen motives had to do with acquiring economic status (98\%) and feeling superior to other professions (94\%) (Treviño et al. 1993). To sort this conflicting evidence, further exploration is needed to understand if the time and status of both populations and of course the instruments used, could have generated such an ambivalence.

With this background, it would seem that the dichotomous approach of intrinsic or extrinsic motivations does not support the complexity of the factors involved in such a decision. For example, another aspect that some studies have highlighted has to do with the age of ideation and decision to pursue that career, due to the high prevalence of individuals who conceive it from childhood (Perales et al. 2014; Molnár et al. 2008) and external influence, particularly of parents in the election (Cardozo, 2009, Santos, 2010, Naipe et al. 2017).

In summary, the variables that have been considered tend to opt for individual factors such as gender, age of ideation, the reproduction of the profession in the family or the desire of the parents. At the macrosocial level (not individual), the identification of the country has been the only factor explored, referring to the level of income as the possibly explanatory reference.

In the meantime, few studies have problematized the relationship that motivations have on new generations of applicants in the face of the transition faced by the medical profession conditioned by a series of organizational and social changes (Mólnar et al. 2008) or the fact of exploring motivations of students while they are further advanced in the program and not only at the beginning.

On a different note, a study in Hungary showed that approximately $24 \%$ of students would not choose a medical career again (Girasek, 2011). Indirectly, this figure reveals a gap between the expectations of the students and the reality they faced in the process of becoming doctors. This could imply that the motivations of these students were not aligned (to some extent) with what the career involved.

The changes that the last decades have brought upon the medical profession and the delivery of healthcare, including rapid growth of information and technology and other socio-organizational tendencies like the rise in the administrative logic and commercialism have conditioned the way the profession works and how it responds to society's needs (González-Amarante, 2021).

Considering these gaps in the literature and the changing context, the present study attempts a qualitative approach to explore the motivations of medical students, with the aim of understanding, beyond the discourse, what other factors influence their motivations and decision.

\section{Methods}

55 semi-structured interviews were conducted between 2015-2019 with medical students from 3 schools in Monterrey, corresponding to one public and two private institutions. The reason for the ample time frame for data collection ocurred because some students were re-interviewed a second time as a part of a doctoral dissertation project with wider objectives. The sample consisted of 31 men and 24 women between 17 and 23 years old. The sample was obtained by the snowball technique and thematic saturation was confirmed (Martínez-Salgado, 2012).

The interview as a method for collecting and producing information is relevant since it extracts the respondent's perspectives regarding what is most significant to him or her. In addition, the fact of 
eliciting speech in free format allows the flexibility to redirect questions until obtaining the desired information (Hardin, 2013). In this sense, the qualitative approach is key to understanding meanings and relationships between people's stories and their behaviors and allows us to approach reality by understanding it as a social construction, which is relevant for interpreting individual stories but above all for understanding phenomena at a social level which is most consistent with a phenomenological and grounded theory approach (Berger and Luckmann, 2001, Vasilachis, 2007, Denzin and Lincoln, 2013).

Verbatim transcripts were coded in the MAXQDA software through iterative rounds of thematic analysis including in vivo and some theoretical informed categories. The relevant code for this analysis corresponded to: a) Motivations to study medicine. All coded excerpts were analyzed to find relevant thematic avenues and perspectives. The gender factor, stage of the career and the presence of familial reproduction of the profession were considered in order to detect possible patterns according to these conditions. The interpretive analysis was carried out with the grounded theory approach (Soneira, 2007).

On the understanding that motivations include motives or reasons that guided or encouraged the desire and decision to pursue a medical career, some specific questions from the script were: - Why did you decide to study medicine? $\bullet$ How did you choose the school? $\bullet$ At what point did you make the decision to study the career? $\bullet$ What did your parents think about your decision?

Additionally, other inquiries included learning the presence of physicians in the family or other referents, and about personal or family experiences that had sensitized them or made them interested in the medical world. However, all allusions to the topic that emerged throughout the interview (which explored other topics from their experience as students) were coded.

Regarding the ethical aspects, the interviewed subjects were approached without institutional mediation, and gave their consent to participate. Confidentiality was protected at all times; numerical codes were used to avoid possible identification of the participating subjects during the analysis process.

\section{Results}

It is important to note that students at different moments of the undergraduate program had very similar responses. That is, it would seem that all responded with respect to the same moment in time, as if they were positioned prior to their entry to the career, which was when they made their decision. The minimum differences detailed according to stage are clarified when it is considered pertinent in the subsequent text.

Regarding the themes that emerged, the most prevalent reason $(n=22)$ for choosing medicine had to do with the interest in medical science. These students show an intellectual or academic orientation, presenting curiosity and desire to learn about the content of the discipline. Many of them realized or reinforced this aspiration through their experience during middle school or high school biology courses. The second reason $(n=16)$ ), encompassed all allusions that had to do with the admiration or aspiration to the position and social honor that the figure of the doctor embodies. On third place $(n=13)$ were the reasons that explained it based on the fact that they had a physician in the family, 
who generally corresponds to father or mother. Next, $(n=9)$ the students reasoned about an experience of illness or a medical encounter that made them take interest in the profession; it is interesting to note that most of them corresponded to students on preclinical stage, which may account to a closer posture from the lay-person perspective. Finally, the least apparent reason $(n=6)$ was the motivation to help as a reason for choosing this profession.

Regarding these findings, it is worth noting that the students could have given answers that were coded in more than one of the themes, or in none of them. The ones that overlapped the most were the two most frequent, the interest in science and consideration of social prestige, with a total of 5 cases. This shows how intrinsic and extrinsic motivations are not exclusive when we consider individuals and can complement each other for decision-making.

Beyond these 3 overarching themes brought up in the student's discourse which generally explain the conscious reasons for their admission, the most revealing findings were three conditioning factors that influenced their decisions. First, the fact that almost half of the students (26 cases) admit having ideated the plan of becoming physicians since childhood. Second, that more than a third of the students (20 cases) did not provide clear reasons for their decision. And finally, a smaller proportion of students (12 cases) consciously acknowledged and reported external influence affecting their professional choice.

These findings broaden the understanding of the factors that influence student motivations, implying that students explain their decision in a superficial and relatively irrational way. Several cases of students presented the combination of 2 or even the 3 factors mentioned and only a quarter (14) of the students were exempt from these 3 factors.

Deepening on the first factor, the ideation since childhood applies to those students who proudly admit their early vocation. Ideation refers merely to conceiving the idea or possibility. On the other hand, decision refers to the conscious resolution at the moment in which that plan is formally ratified. Students admit to having had the first ideations in infancy and childhood, some from preschool age (2-3 years). In 12 of the 26 cases, the students did not complement their explanation with a more rationalized justification at a later stage, overlapping with the cases in which they present external influence and/or have an amotivational stance.

With respect to students who exhibit amotivational postures, it means that individuals cannot give clear reasons or justify their decision beyond arbitrary or circumstantial aspects, or the fact that they themselves admit that they "do not know" why they chose to study medicine.

In the case of external influence, the student is aware that he or she received a specific suggestion from an outsider that affected either ideation or decision. This influence usually comes from parents, teachers, or friends, in that order. This does not exclude that other students were influenced by their parents' expectations or other factors, but it was not the most determining factor, or the main reason that they conceptualized. That is, they could have received influence on the ideation, but also appropriated or constructed other reasons to justify their decision, which may be the case for individuals with a history of physicians in the family. Table 1 cites example quotes that illustrate the occurrence of these three aspects. 
Table 1: Quotes illustrating main 3 findings.

\begin{tabular}{ll}
\hline Findings & Example quotes \\
\hline $\begin{array}{l}\text { Ideation or decision since } \\
\text { childhood }\end{array}$ & "Well, since I was little, I saw doctors how they could heal people simply by \\
& looking at them, touching them, or doing a physical exam to know what they \\
& had, so I said, oh, I want to know that!" \\
& "Since I was 2 years old, I used to go to hospitals with a toy stethoscope that \\
& they had bought me, and I began to ask people to let me hear their heart, I \\
& have always liked the heart very much. And I had my little toy doctor's case \\
& and I played with my little sister who was later born, with my parents, with \\
& my uncles... I said when I grow up, I want to be a doctor."
\end{tabular}

Amotivational postures

"I wanted to study medicine since 3 rd grade, I mean, I knew what medicine was, where the faculty was and since I was a child it attracted me, there was no reason, all of a sudden "I want to study medicine" and then that was when I saw the programs from Dr. House, Grey's Anatomy, but it was before I watched the shows."

"Well, medicine was not one of my priorities to begin with, the truth was a scholarship opportunity that came from my dad's job, so I entered the first semester with the idea that maybe I was going to leave, because if I was entering another career, I had to sign with my father's company that I was going to work for them... and if I entered medicine there was no problem, but I entered the first semester and I liked it a lot and I did not leave."

External influence

"I decided to study medicine in the first year of high school, I was doing social service and the director of that department told me -Why don't you study medicine? You are doing very well (academically), and one of the missions of this high school is to send someone, a representative to the most difficult program and I had never considered it before."

"And on the other hand, my father told me that I should study (medicine) because my father studied medicine for about 1 year, but he had to leave it for economic reasons ... now he was very happy because it was like following his dream and that was also what motivated me to study medicine so that my father could see what it is really like to be a doctor."

An interesting finding that was recorded throughout the coding is the fact that 7 students spontaneously mentioned that a factor that stimulated their interest in the career was having watched television series where they admired the profession and its lifestyle. Of these cases, the majority (4) were in the preclinical stage. This could mean a trend about the influence of television series in recent generations, or the fact that older students did not remember or did not admit that as a factor.

It should be noted that no single student explicitly mentioned income as a reason for becoming a physician. However, most of them assume that the career supposes a prosperous or at least stable economic future, evidenced in the projections about their career. The fact that they do not mention this motivation directly could be due to the fact that they have internalized the convention that the profit motive is not well seen, in favor of a vocation of disinterested service. Of the total sample, only 2 students stated in their history a clear motivation of social mobility, both cases, motivated by their parents who practice health professions with lower status (nursing and physical therapy). 
Table 2: Explicit reasons in student's discourse versus factors that influence motivations.

\begin{tabular}{|c|c|}
\hline Reasons to choose the medical profession. & $\begin{array}{l}\text { Factors that influence ideation and/or } \\
\text { decision of becoming physicians. }\end{array}$ \\
\hline \multirow{8}{*}{$\begin{array}{l}\text { - Interest in the contents of medical science. } \\
\text { - Prestige or social status (directly or indirectly) } \\
\text { - Interest in helping, altruistic or service vocation. }\end{array}$} & - Desire or pressure from parents. \\
\hline & - Proximity of family medical models and \\
\hline & lack of exposure to other professions. \\
\hline & $\begin{array}{l}\text { - Idealization of the figure of the physician } \\
\text { during childhood. }\end{array}$ \\
\hline & - Influence of television programs. \\
\hline & $\begin{array}{l}\text { - Medical encounters lived as patients where } \\
\text { they admire the figure of the doctor. }\end{array}$ \\
\hline & $\begin{array}{l}\text { The notion that the career ensures future } \\
\text { economic stability / prosperity and social } \\
\text { rewards. }\end{array}$ \\
\hline & - Aspiration of social mobility. \\
\hline
\end{tabular}

\section{Discussion}

The main contribution of this paper is to distinguish the subject's motives, which are generally coined as their motivations, versus the influential factors exemplified in Table 2. This is insightful as it recognizes the reasons given by the students in their discourse, which generally correspond to the most frequent approaches, but broadens the possibilities of understanding the factors that in turn influence these reasons. As kind of meta-perspective that looks at what causes or determines their motivations.

The 3 key findings about the high prevalence of amotivational postures, ideation and/or decision since childhood and the presence of external influence in choosing their profession provided a deeper insight on how reasons in the subject's discourse typically match expected motivations and may unconsciously bear other socialization processes of which they are not completely aware.

With respect to previous empirical studies, there is relative congruence with the findings of Goel and colleagues who had reiterated the social status and parental desire as factors for upper-middle-income countries such as the case of Mexico (2018). The results from this study also echo findings about students who opt for medicine because they do not have a defined career plan and are influenced by family members (Pruthi et al. 2013). Regarding gender, in this study no significant differences were found.

Another result that supports the findings of the studies by Perales and collaborators (2014) and Molnár and colleagues (2008) is the high proportion of students who showed interest in becoming physicians from an early age. For this study, the distinction of ideation and decision was made to understand when interviewees rationally appropriated such early interest in a more conscious way later in their process.

Regarding the method, the interview format evidenced information that might not have been captured in a test or survey. On the one hand, the fact of provoking free speech (without predetermined responses) could eliminate some biases by typifying motivations in the traditional way where students could respond based on what is expected or better accepted. Thus, given that intrinsic motivators, especially those of altruistic interest, are the most compatible with the classic professional ethos. In addition, the coding of an extensive interview enables the possibility of triangulating other portions of 
the discourse beyond the segments triggered directly on the subject. Another interesting factor that could have influenced in showing greater nuances is that the students are in a safe context to express themselves freely, that is, the interviewer did not represent an institutional figure and their eligibility for the career was not on trial.

With respect to the discovered factors that underly their motivations, the fact that the figure of the doctor is emblematic for individuals since their childhood, could be due to the fact that medical work is the type of trade to which a person is most likely exposed from an early age and that can be observed in a direct or close relationship, similar to the profession of teacher and in contrast to professions whose work is not oriented to direct human contact or at that stage. This could support the fact that medical students characteristically choose their career earlier than other pre universitarian peers aspiring to distinct professions (Soria et al. 2006).

The admiration for the physician (in the conceptualizations of childhood), the amotivational postures that do not expose solid or rational reasons for choosing the profession and the external influence to opt for this path, can be at least partially explained by the social imaginary that has historically maintained the profession in a privileged position. This high social esteem comes from the honorability of the medical ethos that supports the vocation of service, and the value of rationality and science as central standards. Historically, these professional attributes have enhanced the figure of the doctor, so the culture and socialization to which these students have been exposed since their childhood could be influencing the aspiration of their parents and themselves to become doctors and embody these laudable attributes linked by default to social and economic rewards.

What is worth problematizing is that recently there is a growing ambivalence about the confidence and the status of the doctor in front of society, conditioned by a series of technological, organizational and social changes that, from the aspect of social admiration, have shaken the classical precepts of the profession, and regarding the social rewards, have shown the difficulties of the labor market (Freidson, 2001, Timmemans and Oh, 2010, Nishijima and Blima, 2016, González-Amarante, 2021).

In this sense, it is clear that, in the social imaginary, the notion of the Golden Age of the profession prevails, maintaining the idea that the medical career constitutes a source of important social mobility that does not incorporate the recent organizational and working transitions. A study that analyzes their conceptualization of the status of doctors would be useful to determine the extent to which they influence their pre-notions to choose this profession.

Among the limitations of this study is the fact that individuals were interviewed in different moments of the program, which may not preclude that they can remember the reasons for their decision before entering, or that they have become biased with their experience as medical students. Another aspect to consider is that the data collection occurred over a three year period, which may have accounted for differences in the perceived sociopolitical context, although no critical events were noted.

Further, it would be very interesting to reassess this issue considering the recent experience of the pandemic and how the whole word (including future aspiring physicians) are learning and envisioning their relationship with medicine and the healthcare professions. 


\section{Conclusion}

The qualitative approach discovers clues that denote greater depth and complexity in understanding motivations and factors that influence the aspiring physicians' decisions, without any intent of prescribing the appropriate motivations to aspire to the profession.

The findings of this study suggest that most of the students opt for the profession lacking enough rationality and autonomy to understand the implications of studying and professing this career. The fact that they hold an idealized notion of the profession without weighing the real implications of studying the career and especially without considering the transition that is taking place in terms of the decline in professional status can be problematic. Thus, because the mismatch of expectations could disappoint students in the process, encompassing both academic and motivational problems (McManus, 2006). Further, this may be related to low job satisfaction in the future, without mentioning the implications that transcend to their performance with their future patients

Another aspect worth questioning for future explorations is whether the most prevalent motivation found in this study naturally matches the medical training mainstream paradigm, that highly privileges a clinical path, and expects humanitarian and empathetic competencies. Thus, given that the interest in science, which was the foremost mentioned, does not necessarily preclude identification with a professional path that encompasses close contact with patients.

In short, the apparent motivations behind the medical student's decision can be both arbitrary and deeply complex, but that goes beyond what medical schools can examine in their admissions role. However, medical schools should maintain interest and research on this topic, to incorporate it when they are on the look for the most fit prospects, and not only privilege academic criteria.

And above all, medical schools should educate the applicants and their parents so that they can anticipate the implications of the career and the future employment perspective. This could improve the chances of aligning the expectations and aspirations of young candidates (and their parents) with the current context of the profession.

\section{References}

Berger, P. and Luckmann, Th. (2011), La construcción social de la realidad. Buenos Aires: Amorrortu.

Cardozo R. (2009) Motivación y características socio-demográficas de los estudiantes de Medicina de la Universidad de Carabobo, Venezuela y de la Universidad Autónoma de Madrid, España, 20092010. [Published doctoral thesis] Universidad Autónoma de Madrid. Retrieved from https://repositorio.uam.es/handle/10486/5982

Denzin, N. Lincoln, Y. (2013) Collecting and Interpreting Qualitative Materials $4^{\text {th }}$ edition. USA: SAGE

Fernandini GL. (2018) Factores asociados a la motivación económica de estudiar medicina en estudiantes de medicina de la region de Lambayeque. [Unpublished bachelor's thesis]Universidad de San martin de Porres. Facultad de Medicina Humana. Retrieved from https://hdl.handle.net/20.500.12727/3204

Flores M. Góngora JJ, López MV, Eraña IE. (2019)¿Por qué convertirse en médico?: la motivación de los estudiantes para elegir medicina como carrera profesional. Educación Médica, 21(1), 45-48. DOI: 10.1016/j.edumed.2019.01.002 
Foong C., Nik Nazri N., Khairul, AH. (2018) I am Becoming a Doctor: Mine or Someone Else's Will? Or Does it Even Matter? A Qualitative Investigation. Eurasia Journal of Mathematics, Science and Technology Education, 14(7), 3253-3267. doi:10.29333/ejmste/91680.

Freidson, E. (2001) "La teoría de las profesiones- estado del arte". Perfiles Educativos, XXIII (43), 28-43 Retrieved from http://www.scielo.org. $\mathrm{mx} / \mathrm{scielo}$.php?script=sci_arttext\&pid=S0185$26982001000300003 \& \operatorname{lng}=\mathrm{es} \& \operatorname{tlng}=\mathrm{es}$.

Girasek, E., Molnár, R., Eke, E., Szócska, M. (2011). The medical career choice motivations -Results from a Hungarian study. Central European Journal of Medicine. 6, 502-509. doi:10.2478/s11536011-0034-0

Goel S. Angeli F. Dhirar N. Singla N. Ruwaard D. (2018) What motivates medical students to select medical studies: a systematic literature review. BMC Medical Education,18(1),16. doi: 10.1186/s12909-018-1123-4.

González-Amarante, MP. (2021) Understanding the crisis of the medical profession: a sociological perspective. Revista Mexicana del Seguro Social; 58(3). Epub ahead of print

Hardin, J. (2013) Qualitative data Analysis from Start to Finish. London:SAGE

Lermanda, C., Meyer A. (2014) Single open question study on motivation to medical studies, Revista de Educación en Ciencias de la Salud, 11(2), 129-136. Retrieved from http://www2.udec.cl/ofem/recs/anteriores/vol1122014/RECS1122014.pdf

Martínez-Salgado, C. (2012). El muestreo en investigación cualitativa. Principios básicos y algunas controversias, Ciência \& Saúde Coletiva, 17(3), 613-619. Retrieved from https://www.redalyc.org/articulo.oa?id=630/63023334008

Millan, L., Azevedo, R., Rossi, E., De Marco, O., Millan, M., \& de Arruda, P. (2005). What is behind a student's choice for becoming a doctor? Clinics (Sao Paulo, Brazil),60(2), 143-150. doi:10.1590/s1807-59322005000200011

McHugh, S. M., Corrigan, M. A., Sheikh, A., Lehane, E., Broe, P., \& Hill, A. D. (2011). A study of the factors influencing school-going students considering medical careers. The surgeon : journal of the Royal Colleges of Surgeons of Edinburgh and Ireland,9(4), 191-194. doi:10.1016/j.surge.2010.09.005

McManus I., Livingston G., and Katona C. (2006)The attractions of medicine: The generic motivations of medical school applicants in relation to demography, personality and achievement. BMC Medical Education, 6(11). https://doi.org/10.1186/1472-6920-6-11

Molnár, R., Nyári, T., Hazag, A. Csinády, A., Molnár, P. (2008) Career choice motivations of medical students and some characteristics of the decision process in Hungary. Central European Journal of Medicine, 3, 494-502 doi:10.2478/s11536-008-0063-5

Naipe M., Salabert I., Morales M., Mestre V., Garriga N., Toledo T. Motivation in first-year students of Medicine degree. School year 2015-2016, Revista Médica Electrónica, 39(4). Retrieved from http://www.revmedicaelectronica.sld.cu/index.php/rme/article/view/2089/3563

Nishijima, Y. \& Blima, L., (2016) Medical power and the crisis in bonds of trust within contemporary medicine, Salud colectiva, 12(1) doi: 10.18294/sc.2016.864

Perales, A., Sánchez, E., Mendoza, A., \& Huamaní, C. (2014). Medical vocation in medical students of a Peruvian university, Anales de la Facultad de Medicina. 75(1), 37-42. Retrieved from: http://www.scielo.org.pe/scielo.php?script=sci_arttext\&pid=S1025-

$55832014000100007 \& \operatorname{lng}=\mathrm{es} \& \operatorname{tln} \mathrm{g}=\mathrm{es}$.

Phinder-Puente, M., Sánchez-Cardel, A., Romero-Castellanos, F., Vizcarra-García, J., SanchezValdivieso, E. (2014). Perception of stressors on medical students in the first semester, their parents and teachers, Investigación en Educación Médica. 3. 139-146. Doi: 10.1016/S2007-5057(14)72740-1. 
Pruthi, S., Pandey, R., Singh, S., Aggarwal, A., Ramavat, A., \& Goel, A. (2013). Why does an undergraduate student choose medicine as a career? The National medical journal of India, 26(3), 147-149. Retrieved from: https://pubmed.ncbi.nlm.nih.gov/24476160/

Ryan, R. \& Deci, E. (2000). Intrinsic and Extrinsic Motivations: Classic Definition and New Directions. Contemporary Educational Psychology. 25. 54-67. Doi:10.1006/ceps.1999.1020.

Treto, Y., Caro, Y., Corrales, L., Pérez, M. \& Blanco, K. (2010). Factores asociados al fracaso escolar en estudiantes de medicina del Policlínico Facultad Vicente Ponce Carrasco. Revista Médica Electrónica. $32 . \quad$ Retrieved from https://www.researchgate.net/publication/262657612_Factores_asociados_al_fracaso_escolar_en_estu diantes_de_medicina_del_Policlinico_Facultad_Vicente_Ponce_Carrasco

Soneira, A. (2007) Cap. 4 La Teoría fundamentada en los datos (Grounded Theory) de Glaser y Straus. Vasilachis, I. (Ed). Estrategias de investigación cualitativa. 1era edición. Buenos Aires:Gedisa

Soria M, Guerra M, Giménez I, Escanero J. (2006). The decision to study Medicine: characteristics, Educación Médica, 9(2): 91-97 Retrieved from http://scielo.isciii.es/scielo.php?script=sci_abstract\&pid=S1575-18132006000200008

Timmermans, S. \& Oh, H. (2010) The continued social transformation of the medical profession, Journal of Health and Social Behavior. 51(S)94-106. Retrieved from http://search.proquest.com/docview/762223565?accountid=11643

Torres-Acosta, N., Rodríguez-Gómez, J., \& Acosta-Vargas, M. (2013). Personality, learning and academic performance in medicine, Investigación en educación médica, 2(8), 193-201. Retrieved from $50572013000400004 \& \operatorname{lng}=\mathrm{es} \&$ tlng=es. http://www.scielo.org.mx/scielo.php?script=sci_arttext\&pid=S2007-

Torres-Roman J., Cruz-Avila ., Suarez-Osorio K., Arce-Huamaní M., Menez-Sanchez A., AveiroRóbalo T. (2018) Motivation towards medical career choice and academic performance in Latin American medical students: A cross-sectional study. PLoS ONE 13(10). Retrieved from https://doi.org/10.1371/journal.pone.0205674

Treviño M., Hauad I. , De la Cruz, M., Zárate M. (2013) Factores motivacionales que orientan la decisión de ingresar a la licenciatura en medicina de la Universidad Autónoma de Nuevo León. 1er Congreso Internacional de Investigación Educativa. Retrieved from: http://eprints.uanl.mx/8191/1/z1_1.pdf

Vasilachis, I. (2007) Cap. 1. La investigación cualitativa. Estrategias de investigación cualitativa. 1era edición. Buenos Aires:Gedisa.

Vives-Varela, Tania, \& Durán-Cárdenas, Cassandra, \& Varela-Ruíz, Margarita, \& Fortoul van der Goes, Teresa (2014). La autorregulación en el aprendizaje, la luz de un faro en el mar. Investigación en Educación Médica, 3(9),34-39 Retrieved from https://www.redalyc.org/articulo.oa?id=3497/349733231006

Wasityastuti, W. Yoga Pamungkas Susani. Yayi. SuryoPrabandari. Gandes Retno Rahayua. (2018) Correlation between academic motivation and professional identity in medical students in the Faculty of Medicine of the Universitas Gadjah Mada Indonesia. Educación Médica. 19(1), 23-29. Retrieved from https://doi.org/10.1016/j.edumed.2016.12.010.

Wierenga, A. R., Branday, J. M., Simeon, D. T., Pottinger, A., \& Brathwaite, B. (2003). Motivation for and concerns about entering a medical programme. The West Indian medical journal, 52(4), 304310. Retrieved from https://pubmed.ncbi.nlm.nih.gov/15040068/

Wouters A. Croiset G. Galindo-Garre F. (2016) Motivation of medical students: selection by motivation or motivation by selection. BMC Medical Education 29(16)37. doi: 10.1186/s12909-0160560-1.

Yousefy, A., Gholamreza G., and Samaneh F. (2012) Motivation and academic achievement in medical students. Journal of Education for Health Promotion. 28(1)4. doi: 10.4103/2277-9531.94412 